Guidance Memo prepared for Tiny Beam Fund

November, 2021

\title{
BUILDING \\ BRIDGES TO \\ PROMOTE \\ SUSTAINABLE \\ LIVESTOCK \\ SYSTEMS: \\ opinions of \\ stakeholders in \\ Brazil towards \\ gene editing \\ of farm animals
}

Maria Cristina Yunes

TINY:-

BEAM

FUND 

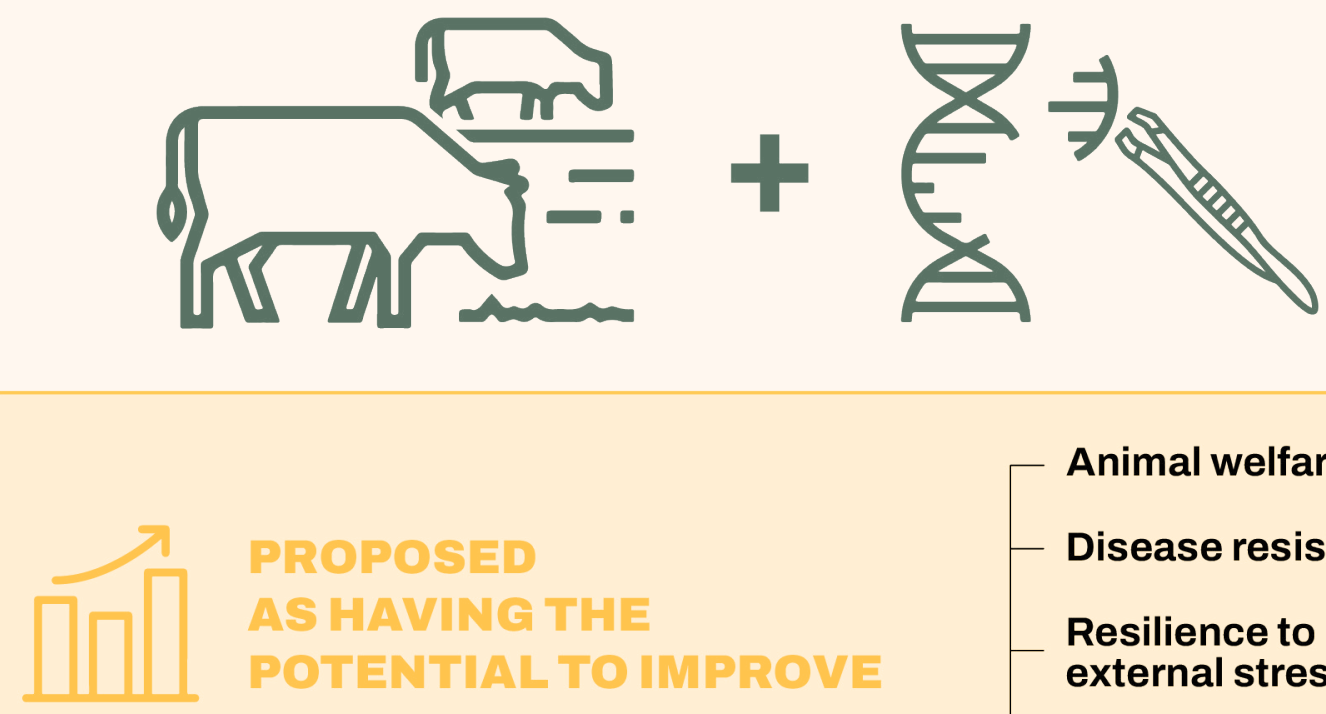

PROPOSED

AS HAVING THE

POTENTIALTO IMPROVE

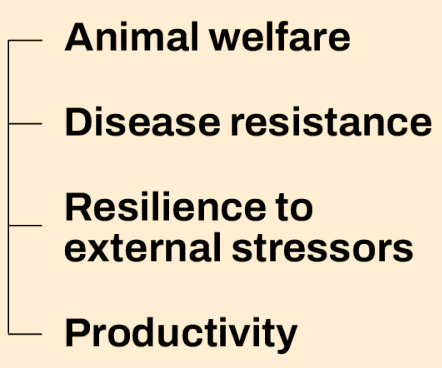

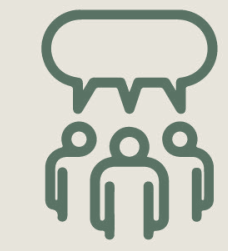

PUBLIC

ACCEPTABILITY

Low knowledge about genetics in general

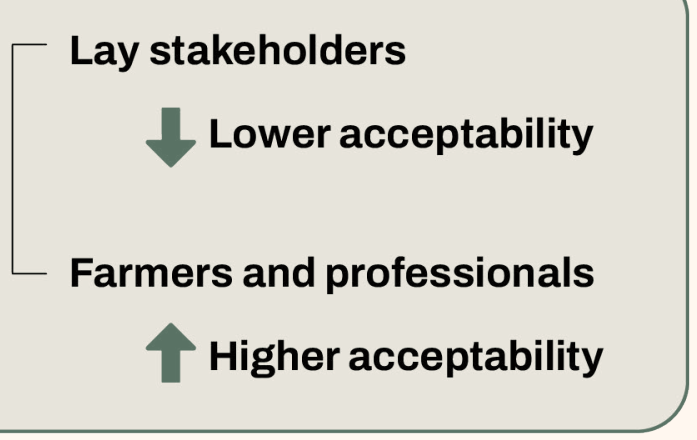

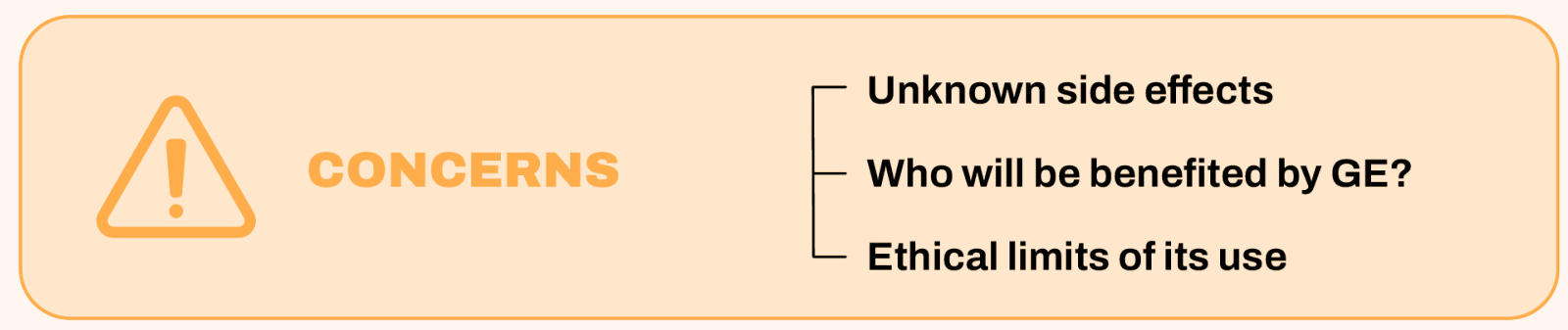
(4)
PERCEIVED BENEFITS

$$
\text { Improvement in }\left[\begin{array}{l}
\text { Animal welfare } \\
\text { Farmers' quality of life } \\
\text { Productivity }
\end{array}\right.
$$

While stakeholders involved with livestock production are open to technological solutions to the problems facing animal production, lay stakeholders prefer systems more natural and animal friendly.

True interest in different points of view can lead to a constructive dialogue and sustainable solutions to livestock production systems.

Most stakeholders agree that animal welfare legislation is a matter of importance to Brazil animal production, and that labeling is a required issue to gene edited products. 


\section{Abstract}

Agriculture production systems have been modified and intensified for more food production, resulting in the industrialization of livestock systems. This means production of animals in smaller spaces, with the aid of antibiotics, food additives, and genetic selection for high production rates. Gene editing of farm animals is a technology of growing importance and has been presented as a potential tool to help solve problems faced by the livestock industry, for example promising improvements in farm animal health and welfare, and productivity. Applications for the farm industry are emerging and yet to receive legal approval before they reach the market. However, there is a growing demand for animal food products originating from ethical agricultural systems. This means that people are concerned with how their food is produced and how different systems may affect consumers, producers, the environment, and the animals. Brazil is one of the world's largest producers and exporters of animal products; the importance of livestock farming for the country's economic performance and job creation is unquestionable. This guidance memo aims to explore the opinions and acceptability of gene editing of farm animals among stakeholders of the livestock chain in Brazil. Farmers and other stakeholders involved with livestock production are more favorable to gene editing of farm animals than lay stakeholders. In general, rejection is related to concerns regarding possible long-term effects of genetic modification on humans, animals, and environment; acceptance, in contrast, is justified by perceived improvements in animal welfare and farmers' quality of life. Acceptance is in great part conditioned to the assurance of safety of the technology and that animals are not harmed. While stakeholders involved with livestock production are open to technological solutions to the problems facing animal production, lay stakeholders prefer systems more natural and animal friendly. Most stakeholders agree that animal welfare legislation is a matter of importance to Brazil animal production, and that labeling is a required issue to gene edited products. The animal agriculture industry should consider Brazilian lay citizens' attitudes and expectations regarding farm animal welfare to develop appropriate solutions that are acceptable for all stakeholders and for the animals. Dialogue and engagement among stakeholders can certainly contribute to the sustainability of farm animal production systems.

\section{Author}

\section{Maria Cristina Yunes PhD in Animal Welfare}

Postdoctoral Fellow at Laboratório de Etologia Aplicada e Bem-Estar Animal - LETA/CCA-UFSC, Florianópolis - Brazil.

\section{Acknowledgements}

I am especially grateful to Dr. Maria José Hotzel (Laboratório de Etologia Aplicada e Bem-Estar Animal - UFSC) for her constant encouragement, supervision and insightful comments that helped to shape this Guidance Memo. To Carmen Lee (Tiny Beam) for her helpful comments and corrections. And to all anonymous respondents and interviewees that kindly accepted to participate in this survey. 


\section{Contents}
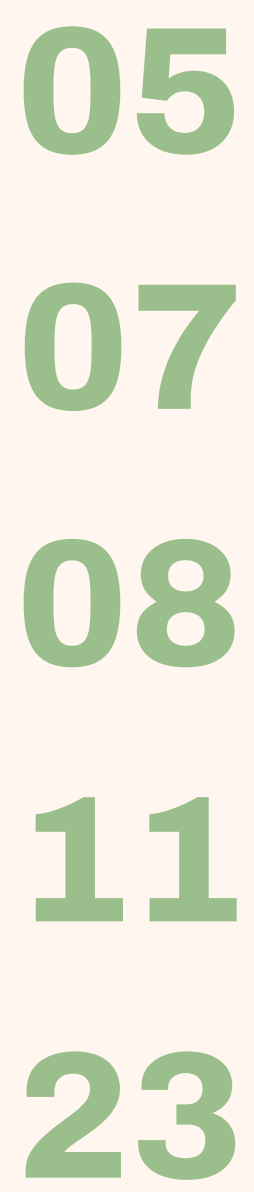

V. STUDY PARTICIPANTS' ATTITUDES IN RELATION TO FARM ANIMAL WELFARE

VII STUDY PARTICIPANTS' WAY OF FINDING

INFORMATION AND WHO TO TRUST

VII. TAKE HOME MESSAGES

REFERENCES

I. WHY THERE IS A LOT OF INTEREST

RECENTLY IN THE ISSUE OF GENE

EDITING IN FARM ANIMAL PRODUCTION?

II. AIM OF GUIDANCE MEMO:

HOW DIFFERENT STAKEHOLDERS IN BRAZIL

VIEW GENE EDITING OF FARM ANIMALS

III. BRAZIL STAKEHOLDERS'

KNOWLEDGE AND ATTITUDES TOWARDS

BIOTECHNOLOGIES IN FOOD PRODUCTION

IV. ATTITUDES OF STAKEHOLDERS IN

BRAZIL TO FARM ANIMALS' GENE EDITING

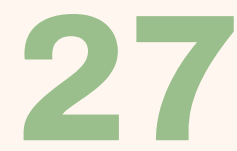




\section{WHY THERE IS A LOT OF INTEREST \\ RECENTLY IN THE ISSUE OF GENE EDITING IN FARM ANIMAL PRODUCTION?}

Gene editing is a novelty in farm animal production. Applications for the farm industry are emerging and yet to receive legal approval before they reach the market. This biotechnology has been presented as a tool to help solve problems faced by animal production, for example promising improvements in farm animal health and welfare (Proudfoot et al., 2020). Gene editing can be more easily and precisely used to alter the animals' genome than previously available genetic engineering technologies and is different from transgenic technology in that it may use the species' own DNA. Perhaps the most attractive characteristic of gene editing is that, unlike conventional genetic improvement, it is expected to facilitate the introduction of individual traits without compromising other characteristics of the animals (Lamas-Toranzo et al., 2017). These improvements can be achieved either by preventing controversial invasive practices or having animals more resilient to environmental adversities (Menchaca, 2021).

Some examples of gene editing of farm animals are the birth of hornless dairy cows, improved heat resistance and resistance to some specific diseases for dairy cattle, boar taint prevention on male pigs, and resistance to African swine fever. Other potential applications target improvements in animal productivity - both in quantity or quality, such as double muscled cattle, sheep and pigs. Therefore, gene editing can be used for purposes that improve productivity and profitability, but also animal welfare and sustainability.

However, public perception of gene editing of farm animals may differ substantially from that of scientists. The lay public considers genetic modification a source of potential harm to people, animals, and the environment. There are many unanswered questions about the safety of the technique, especially about possible unexpected effects of gene editing in the animals (Bruce, 2016). Moreover, some argue that production benefits are the main drivers behind the applications of genetic innovations. Concerns about the use of gene editing technology in animal production are also related to environmental sustainability, human and animal health, animal welfare, as well as the social and economic implications of the technology, including how it would be distributed and which impact it would have on producers, and the ethical boundaries of its use (Shriver, 2020).

There is also a diversity of opinions, preferences, and concerns about the use of animals for food production - in relation to animal welfare, productivity, and food quality among people with different degrees of association with animal production. The current discussion focuses on whether gene editing is just an updated genetic modification or whether it is a helpful new tool to livestock farming. 


\section{KEY MESSAGE}

Understanding stakeholders' attitude can help predict if they will engage in the implementation of the technology or take a position opposed to it. It is essential to include societal input during the initial phases of research and development of new biotechnologies for food animal production. 


\section{AIM OF GUIDANCE MEMO: HOW DIFFERENT STAKEHOLDERS IN BRAZIL VIEW GENE EDITING OF FARM ANIMALS}

This Guidance Memo aims to provide a better understanding of how different stakeholders in Brazil view gene editing of farm animals. It explores:

- Attitudes of extension agents regarding potential impacts on animals' welfare arising from the use of gene editing of farm animals in Brazil.

- Attitudes of farmers towards the potential impacts of the gene editing of farm animals on animal welfare and on production systems in Brazil.

- Awareness and attitudes of stakeholders with different levels of involvement in livestock production in Brazil towards contentious animal production systems and practices, in particular the links associated with the possible use of gene editing of farm animals to achieve animal welfare improvement.

A study was undertaken in 2021 specifically to gather the views of these stakeholders $^{1}$. The study was conducted through an online survey ${ }^{2}$ aimed at different stakeholders involved with animal production, namely farmers, professionals, and lay citizens ${ }^{3}$. A semi-structured interview ${ }^{4}$ with dairy producers and extension agents working with them was also conducted to explore their thoughts and beliefs about gene editing of farm animals.

1 The project was approved by the Ethics Committee on Research with Human Beings of the Federal University of Santa Catarina (CEPSH-UFSC), P. 2.051.639.

2 The questionnaire was composed of closed and open questions, directed to investigate these stakeholders' awareness of genetic modification (GM), attitudes to the use of biotechnologies in animal production and to the use of gene editing (GE) in farm animals, attitudes towards possible changes in the current practices, and views regarding improving animal welfare.

3 Groups were defined as farmers = livestock farmers and other farmers $(n=114)$; professionals = extension agents, veterinarians, agricultural technicians, agronomics and animal scientists, professionals of the animal industry, animal welfare scientists and university and agricultural college teachers $(n=302)$; lay citizens $=$ people not involved with agriculture or animal production $(n=206)$.

4 The interviews were conducted with 4 dairy farmers and 4 extensionist agents with the aim to investigate GE acceptability, reasons, and perceptions of risk/benefits to producers, animals, and society associated with GE. 


\section{BRAZIL STAKEHOLDERS'}

\section{KNOWLEDGE AND ATTITUDES TOWARDS BIOTECHNOLOGIES IN FOOD PRODUCTION}

In addition to their opinions about gene editing in farm animals, stakeholders in Brazil were asked to answer a quiz ${ }^{5}$ on biotechnologies in food production.

\section{SELF-ASSESSMENT VERSUS KNOWLEDGE}

- Stakeholders' self-assessment was in accordance with the actual level of knowledge shown in the quiz. Those who said that they knew much answered more questions correctly and those who said that they knew little made the most mistakes (see Table 1).

\section{Table 1 - Association between self-assessment and knowledge correct answer on the quiz, of $\mathbf{5 7 3}$ stakeholders that answered both questions.}

\begin{tabular}{llll} 
Self-evaluation* & Knowledge & $\mathbf{n}$ & SE \\
\hline Much & $4.04^{\mathrm{a}}$ & 25 & 0.23 \\
Something & $3.62^{\mathrm{ab}}$ & 91 & 0.13 \\
Intermediary & $3.43^{\mathrm{b}}$ & 129 & 0.10 \\
Little & $2.92^{\mathrm{c}}$ & 251 & 0.08 \\
Nothing & $2.16^{\mathrm{d}}$ & 77 & 0.16
\end{tabular}

*How much do you know about gene editing of plants, animals, or humans? ${ }^{a-d}$ Means followed by a different letter are significantly different $(P<0,05)$

- Most stakeholders self-evaluate themselves as having little (43\%) or intermediary (23\%) knowledge about gene editing (GE). This was confirmed in the quiz, where $57 \%$ answered correctly up to 3 of the 5 questions. Only $10 \%$ of the participants correctly answered all questions.

5 Stakeholders were asked to self-evaluate their knowledge on gene editing (GE) from "nothing at all" to "very much", and to complete a knowledge quiz on genetic modification (GM) containing five questions (adapted from Eurobarometer, 2002), with response options as 'true, 'false' and 'I do not know'. 
- Professionals are more knowledgeable on genetic modification (GM) than farmers and lay citizens (see Figure 1).

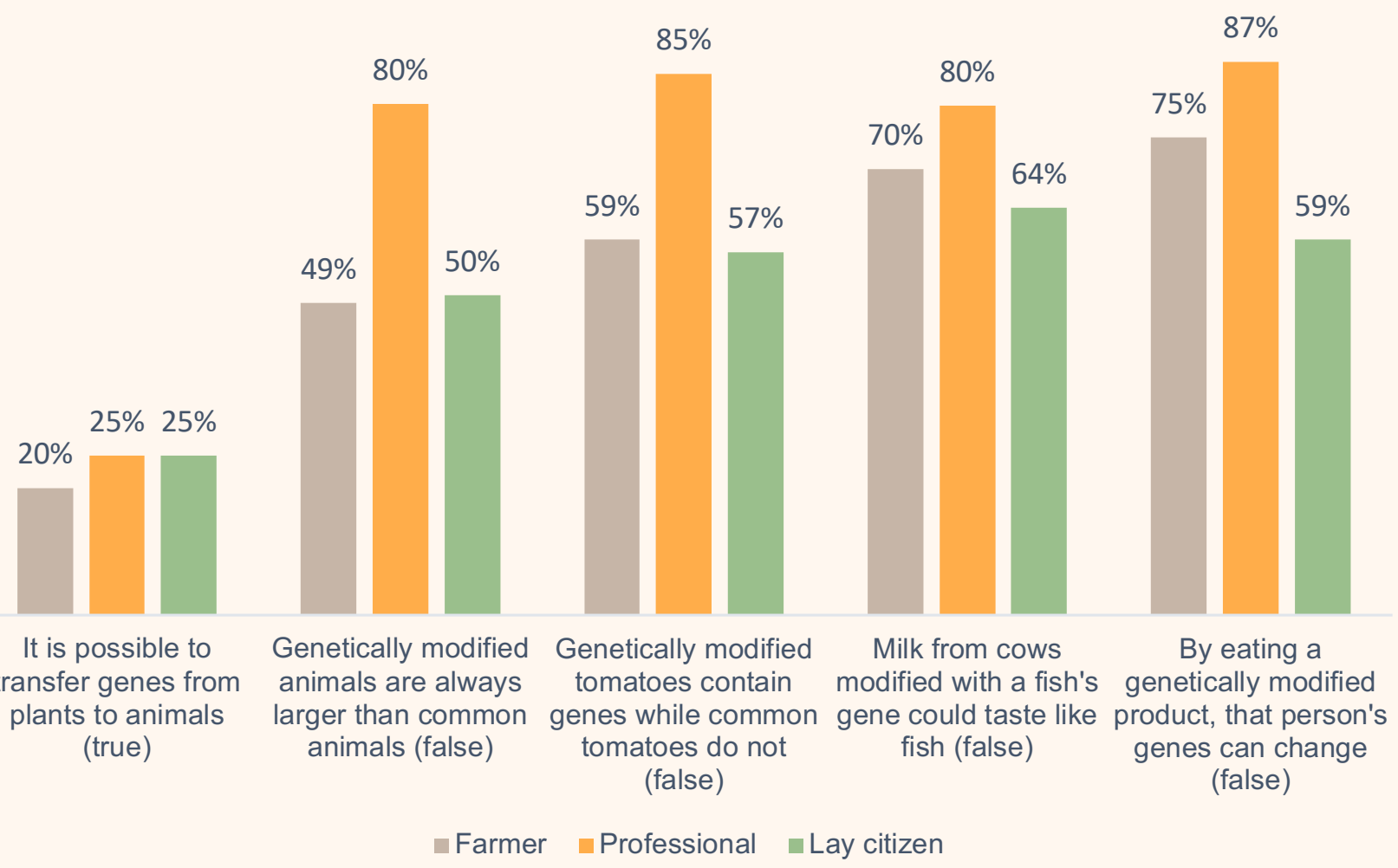

Figure 1 - Correct answers to the knowledge quiz on genetic modification by each group: farmers (gray), professionals (yellow), and lay citizens (green). The quiz had 5 questions and the answer options were "false", "true" and "do not know". 


\section{ACCEPTABILITY OF BIOTECHNOLOGIES IN FOOD PRODUCTION}

- Acceptability of different applications of biotechnology to produce food - genetically modified microorganisms, plants, and cattle - is higher among farmers and professionals than lay citizens (see Figure 2).

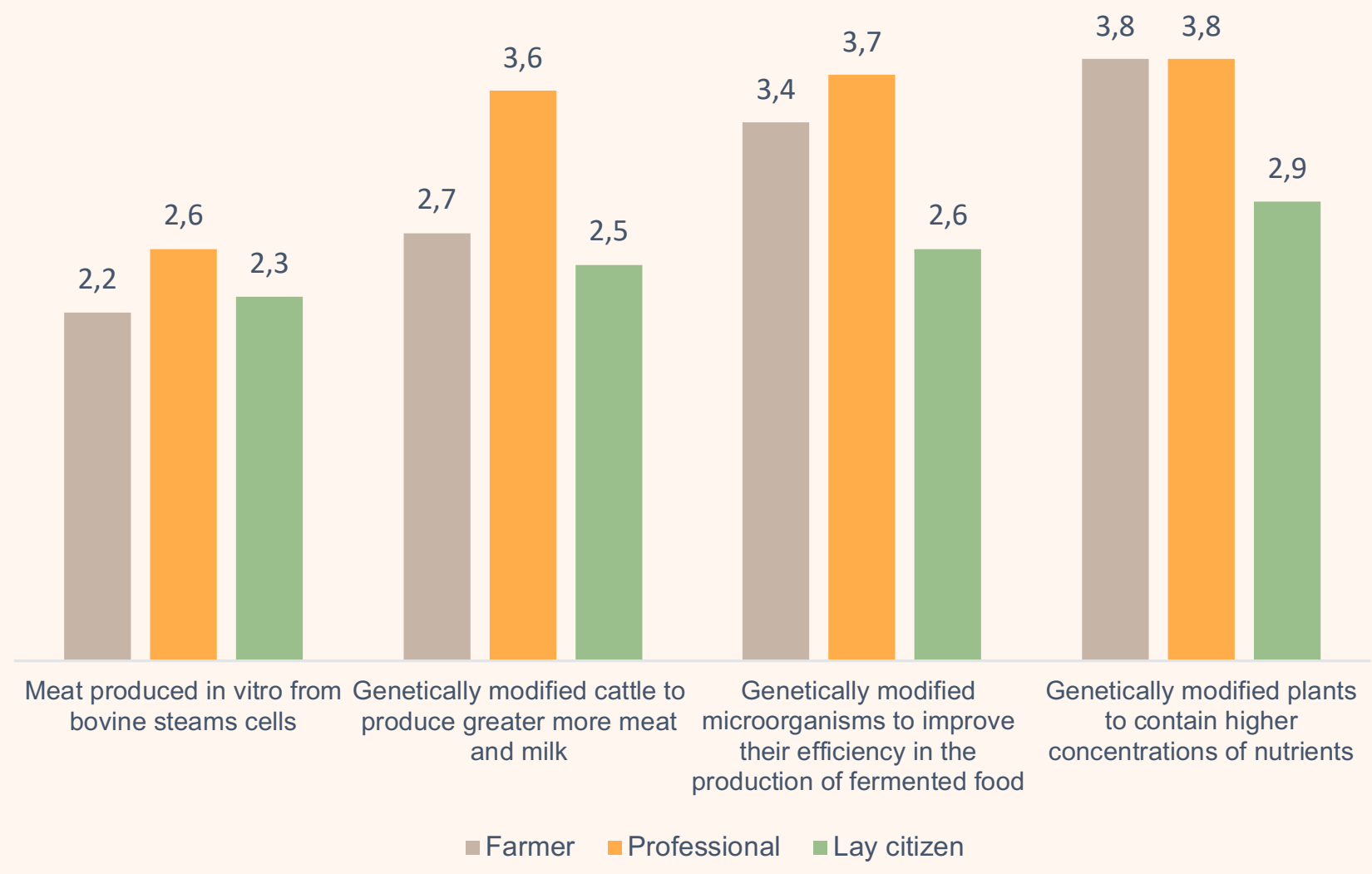

Figure 2 - Average acceptability of each group - farmers (gray), professionals (yellow), and lay citizens (green). - to 4 different biotechnologies used for food production

(going from $1=$ not acceptable to 5 = fully acceptable).

- GM plants are the most accepted biotechnology, followed by GM microorganisms. The aim of the GM technology application influences public views. People are more positive to GM for medical and environmental applications than for food production. Also, the public is more positive to genetic modification of vegetables and microorganisms than of animals.

- Many consumers see non-animal products as a pathway to more sustainable food choices and a way to address the problem of farm animal welfare. Acceptability of meat produced in vitro is low among stakeholders, although professionals accept the idea of cultured meat more than farmers and lay citizens. 


\section{ATTITUDES OF STAKEHOLDERS IN BRAZILTO FARM ANIMALS’ GENE EDITING}

\section{INTRODUCTION: WHAT ARE THE TYPES OF KEY GENE EDITING APPLICATIONS IN CATTLE?}

- Horns: The presence of horns is a very frequent but undesirable trait in dairy cattle as horns make routine handling more difficult and pose danger to humans and other animals in the herd. For this reason, cattle are often dehorned (have their horns removed). The application of gene editing to produce hornless dairy cattle is proposed in this context. It consists of the introduction of a polled gene (hornless trait) naturally occurring in beef cattle, into the dairy genome without compromising genetic merit and milk yield (Tan et al., 2013).

- Thermal stress: Thermal stress occurs when animals are unable to effectively dissipate heat produced either by high ambient temperatures or its metabolism. One mutation found in some cattle breeds was found to be responsible for short, glossy hair and sweat gland density that confer a superior ability for thermoregulation to animals (Sonstegard et al., 2017). The introduction of this gene through gene editing to reduce thermal stress in dairy breeds, without modifying other traits of the breed, is presented as an alternative to improve productivity and animal welfare in European breeds raised in pastures in tropical and subtropical climates that do not have enough shadow.

- Diseases such as mastitis and tuberculosis: The high prevalence of mastitis is a cause for loss of milk, pain, and discomfort to the cows, and is a major cause for the excessive use of antibiotics in dairy production. Tuberculosis is one of the most significant zoonoses and therefore a great public health concern. These diseases cause serious economic losses and damages to the health and wellbeing of animals and humans. GE for tuberculosis consists of integrating an extra gene naturally occurring in cattle, which confers greater resistance to the disease, into the genome of dairy breeds. GE for mastitis, however, differently from the applications described above, is given by the precise insertion of the exogenous human lysozyme gene into the dairy cattle genome. Transgenic cows expressing human lysozyme in their milk are resistant to certain, though not all, bacterial infections responsible for the mastitis (Liu et al., 2014).

- Productivity: Additionally, other applications of GE are proposed that do not deal with health and welfare issues. One example is the production of cattle with increased muscle mass, by the introduction of a gene present in the Belgian Blue cattle breed that silences the enzyme that regulates muscle growth. This application offers productive and environmental advantages, by reducing the use of environmental resources to produce meat, but with possible negative consequences for animal welfare (Menchaca, 2021). 


\section{HOW ACCEPTABLE IS GENE EDITING IN CATTLE TO PARTICIPANTS OF THE STUDY? ${ }^{6}$}

- Acceptability of cattle gene editing is higher among professionals (72\%) and farmers $(68 \%)$ than among lay citizens (36\%).

- Applications with the potential to improve animal welfare and health, facilitate management and reduce costs are more acceptable to all stakeholders (see Figure 3). Mastitis resistance, however, was less acceptable than tuberculosis resistance, probably due to the transgenesis involved in the technique.

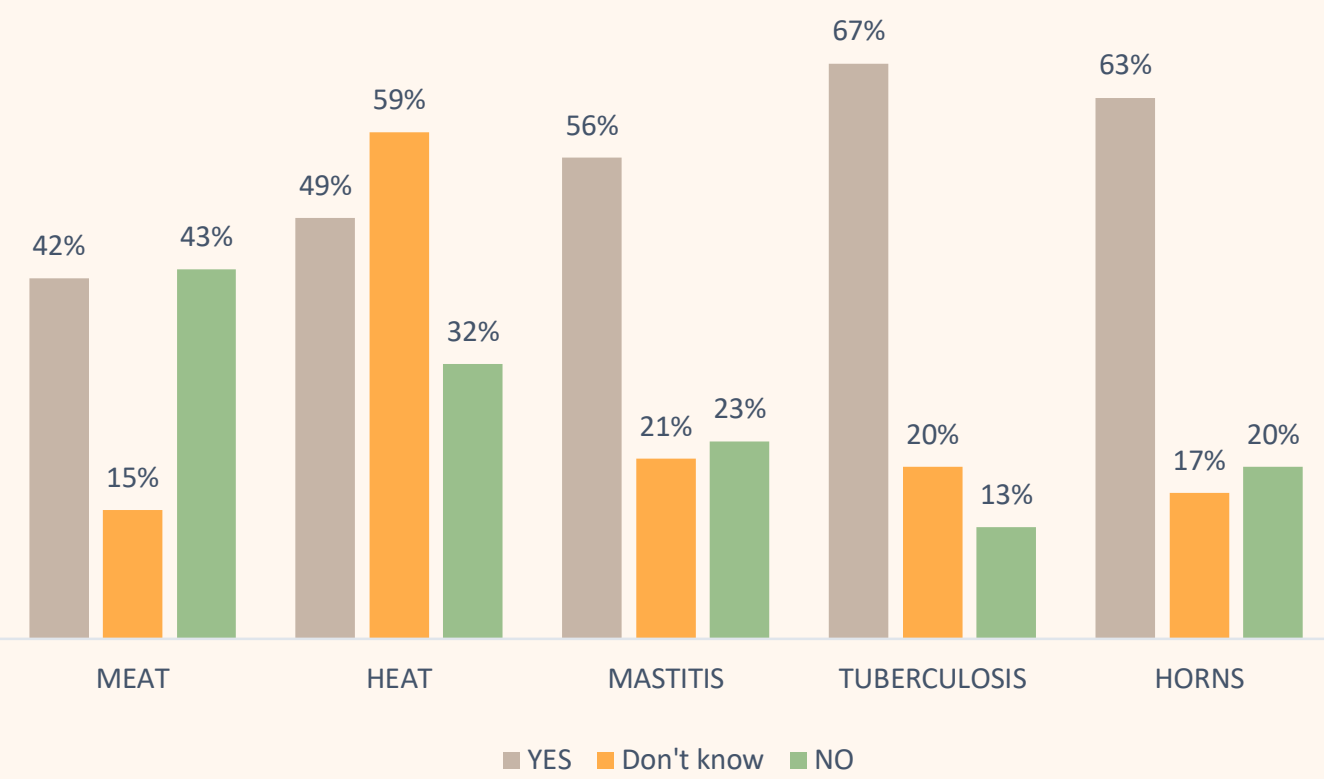

Figure 3 - Stakeholder's acceptability of 5 different GE application in cattle. Percentage that answered "yes" (gray), "do not know" (yellow), and "no" (green) to the question: would you adopt, recommend, or accept the technology?

- Applications that are mostly related to increased productivity are less acceptable among lay citizens, but not among farmers, where $75 \%$ found the application to produce more meat acceptable.

- Dairy farmers and extension agents that participated in the interviews were favourable to all applications presented. They said they would adopt or recommend all the applications, as long as they are used responsibly and there are no problems to animals and consumers related to their use: "I think all of them, used correctly, are good for the producer" (extension agent). Although they were very favorable to GE, they were cautious in conditioning acceptability to assurance of safety of the technology and its ability to improve animal welfare and productivity.

6 Participants were introduced to one of the 5 possible GE applications in bovines (hornless, heat resistance, mastitis and tuberculosis resistance and double-muscle growth) and then were asked questions about the application acceptability and risk/benefits perceptions. Interview participants were introduced to all applications before the interview. 


\section{HOW ACCEPTABLE IS FOOD PRODUCED BY GENE EDITED ANIMALS TO PARTICIPANTS OF THE STUDY?}

- Most farmers (75\%) and professionals (81\%) accept the idea of feeding their families with food produced by gene edited animals.

- The fact that there are already so many foods that cannot be considered as natural in people's daily life is a current consideration to accept GE food: "we already eat so many things... Most crops and other growings are already transgenics and we all eat them" (dairy farmer); "I believe there will be space for everything, there will be those who won't eat at all and there will be those who think it's good because the animal suffered less and there will be those who don't care...if price is interesting..." (extension agent).

- Less than $40 \%$ of lay citizens accept the idea of feeding their families with food produced by gene edited animals; this is probably related to the low acceptability of the technology itself.

\section{WHAT ARE STUDY PARTICIPANTS' PERCEIVED RISKS}

\section{AND BENEFITS OF GENE EDITING TECHNOLOGY?}

Risk perception, rather than the technical risk provided by experts, drives people acceptability to new technologies (Frewer et al., 1998). The public questions the need for a new food technology when no benefits are perceived, which may also raise perceived risks and moral concerns. But if they perceive the technology as useful and morally acceptable then they may discount risk (Gaskell et al., 2006). Also, risks and benefits are inversely correlated in people's minds, i.e., higher perceived risk is associated with lower perceived benefit and vice-versa.

In general, GE is seen as beneficial and with low risks by participants of the study. None of the five applications presented - hornless cows, heat resistance and mastitis or tuberculosis resistance for dairy cattle and double muscled beef cattle - is perceived to be more beneficial or riskier than the other (see Figure 4). Lay citizens perceive GE riskier and less beneficial than farmers and professionals (see Figure 5). 


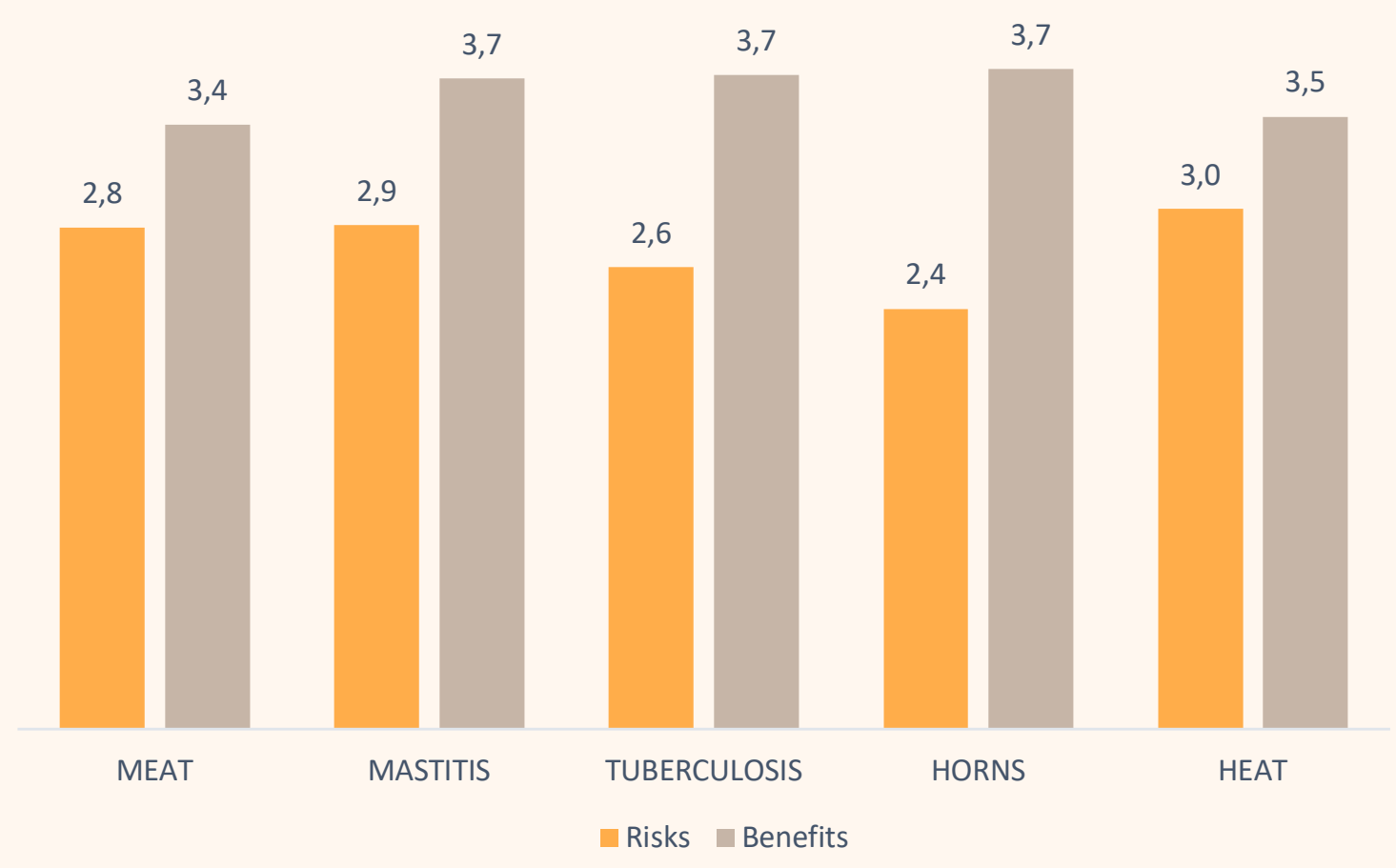

Figure 4 - Stakeholders' average perception of risks (yellow) and benefits (gray) of the use each application: meat production, mastitis resistance, tuberculosis resistance, hornless, heat resistance.

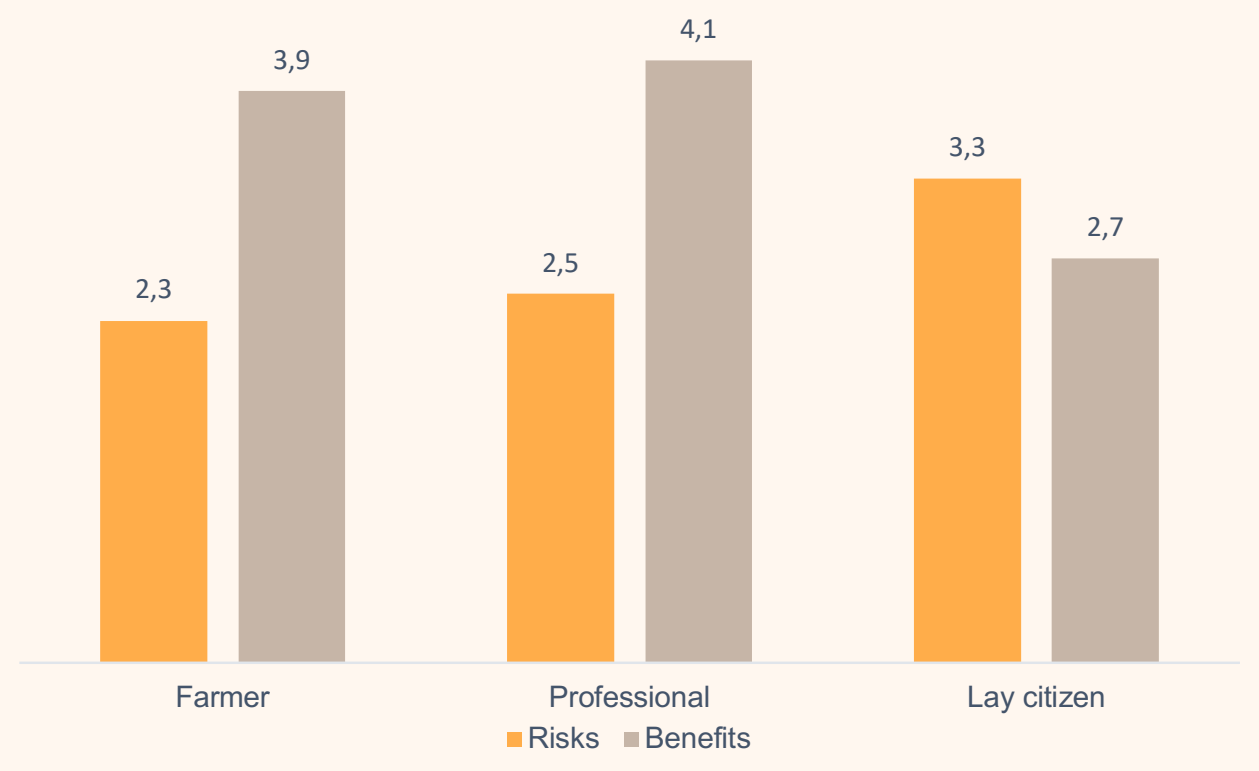

Figure 5 - Farmers, professionals, and lay citizens' average perception of risks (yellow) and benefits (gray) of the use of GE in farm animals $(1=$ no $\mathrm{risk} /$ benefit to $5=$ much $\mathrm{risk} / \mathrm{benefit})$. 


\section{Risks}

- Over half $(52 \%)$ of the lay citizens perceive much or some risk, whereas most farmers $(60 \%)$ and professionals (56\%) perceive little or no risk from the use of the technology.

- Stakeholders share the opinion that the uncertainties of the technology, like unknown and unexpected long-term side effects in both animals and humans, is the main risk coming from livestock GE. They worry mostly about the potential damage to the health of animals and humans.

- Lay citizens are also concerned about possible environmental negative impacts of adopting GE applications, such as deforestation and pollution. Some worry about animal suffering, animal genetic loss, and other ethical issues. Also, some worry that this could contribute to a new pandemic coming from these systems.

- Farmers and professionals also worry about the ethical boundaries of the technology.

\section{KEY MESSAGE}

Although not knowledgeable of the particularities of genetic modification, Brazilian stakeholders are aware of the difficulty to predict the effects that a specific genetic modification can have on an individual animal, and therefore perceive it as the main risk of the gene editing technology. 


\section{Benefits}

- In general, lay citizens perceive less benefit coming from the use of the technology than farmers and professionals; $47 \%$ of lay citizens perceive none or little benefit, while $67 \%$ farmers and $75 \%$ professionals perceive much or some benefits.

- Benefits perceived by lay citizens include the potential to decrease animal suffering and pain - from dehorning or disbudding or from diseases such as mastitis. They also see benefits in the potential improvement in productivity.

- Farmers and professionals view many benefits to animals and humans. This is associated with perceived potential improvement in animal welfare via the reduction of painful procedures, or by making animals more resistant to external stressors and improving animal health and, thus, the reduction of use of antibiotics. They also perceive benefits to farmers associated with the potential of GE to improve productivity, reduce stressful managements like dehorning, injections, and others. Farmers and professionals see benefits to society as well, given the better-quality (e.g., by reducing the need to use antibiotics) or cheaper products: "I see it as a safer food production, you're not adding a product, it's one less product, one less residual... It's a characteristic that comes from the animal and helps fight problems in another way" (extension agent).

\section{KEYMESSAGE}




\section{HOW POSITIVE OR NEGATIVE DO PARTICIPANTS OF THE STUDY CONSIDER THE IMPACTS OF GENE EDITING TO BE?}

- In general participants perceive more positive than negative impacts coming from GE. The most positive impacts perceived are on the economic production performance, on the solution of livestock problems, and on the quality of life of the producer (see Table 2).

Table 2 - Stakeholders' perception of the impact of GE on the animal production chain (going from $1=$ very negative to $5=$ very positive) *

\section{Impact of gene editing}

On the consumer perception of the final product

On the quality of life of animals

On the sustainability of the system

On the quality of life of producers

On the solution of animal production problems

On the economic performance of production
Farmer Professional Lay citizen

$3.2 \mathrm{a} \quad 2.91 \mathrm{a} \quad 2.47 \mathrm{~b}$

$3.93 \mathrm{a}$

$3.72 \mathrm{a}$

$2.67 \mathrm{~b}$

$3.93 \mathrm{a}$

$3.78 \mathrm{a}$

$2.69 b$

$4.05 a \quad 3.96 a \quad 3.4 b$

$4.16 a \quad 3.93 b$

$3.02 \mathrm{c}$

$4.27 \mathrm{a} \quad 4.22 \mathrm{a}$

$3.55 \mathrm{~b}$

* Letters indicate differences across the line. Data were compared with Kruskal-Wallis tests (including a Bonferroni adjustment for multiple comparisons) $\mathrm{P}<0.001$

- Farmers and professionals are more positive than lay citizens regarding all potential impacts of farm animals' GE - quality of life of animals and farmers, consumer perception of product quality, sustainability of the system, economic production performance, and the potential to contribute to the solution of animal production problems.

- Farmers have more positive beliefs than professionals about the contribution of GE to help solve problems of the production system.

- The most negative impact perceived is on consumer perception of the final product. This aspect is cited as a main concern by farmers and extension agents in the interviews. They are aware that the use of GE can add to the public's growing concerns regarding technologies used in agriculture that are considered risks to human, animal, and environment, such as antibiotics, synthetic hormones, and pesticides.

- Interviewees compare the potential reaction of Brazilian lay citizens to GE to their reaction to GM crops when they were first released: "When the transgenic corn entered agriculture there was resistance. Today there is still resistance, but it's a consecrated technology. You don't move it anymore" (extension agent). 


\section{KEYMESSAGE}

Lay citizens are less positive about the impacts of GE than farmers and professionals. 


\section{WHAT ARE STUDY PARTICIPANTS' CONCERNS RELATED TO THE USE OF GENE EDITING IN FARM ANIMALS?}

- Half of the stakeholders worry about a possible misuse of the technology (see Figure 6). The boundaries of GE and the correct application of the technology is a frequent concern raised also by dairy farmers in the interviews.

I don't agree to genetically modify animals

This technology is ethically questionable

There is not enough guarantee of safety

This technology will not be accessible for small and medium-based producers

I'm afraid of unexpected adverse effects

There is the possibility of misuse of this technology

I believe that this technology will strengthen industrial systems of animal production

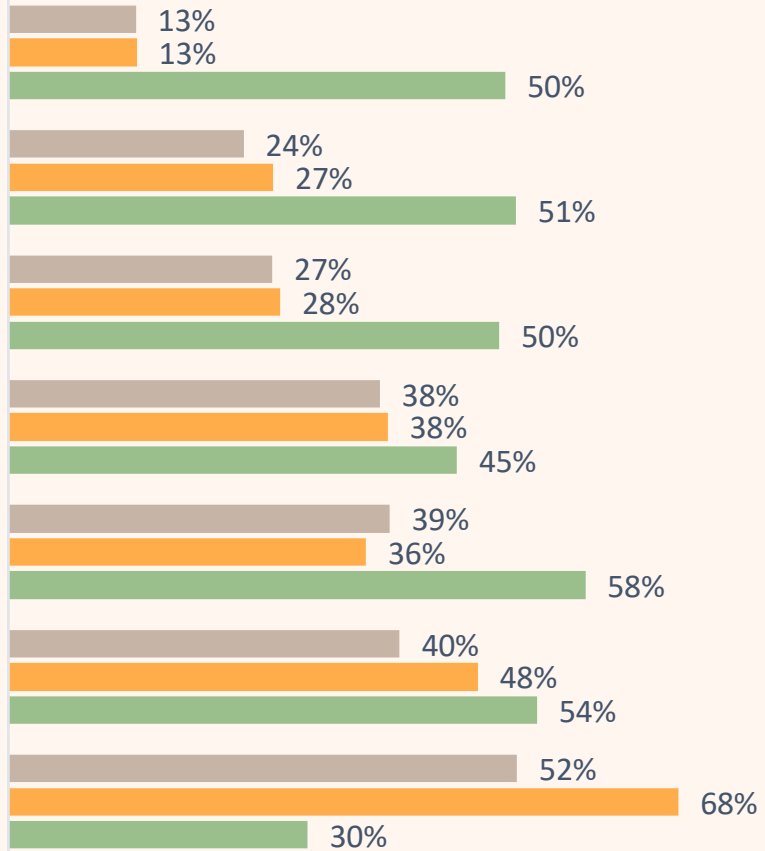

$30 \%$

- Farmer Professional Lay citizen

Figure 6 - Percentage of farmers (gray), professionals (yellow) and lay citizens (green) who agree with each statement presented.

- Many of the stakeholders (40\%) believe that GE will not be accessible for small and medium-based farmers, who may become unable to compete with larger producers. This is a common concern regarding the application of new technologies in agriculture. When asked about it on the interviews, dairy farmers and extension agents do not show real concern, rather considering it as something they are used to facing: "new technologies are always expensive and restricted to some at the beginning, but with time it arrives to everybody" (extension agent) and "I think that at first it will be more difficult for the small producers to have access to gene editing, but after the idea is more advanced, I think they will not have so much trouble" (dairy farmer); "It may be expensive at first, but with time it gets better. Every day a new technology is entering the farms and improving them. But we must have governmental support, to achieve a strong production chain in the region" (dairy farmer). 
- Most professionals (68\%) and farmers (52\%) interviewed believe that GE will reinforce industrial animal production systems. Dairy farmers and extension agents interviewed perceive this to be something that strengthens the possibility to produce more and at lower prices to consumers, without harming animal welfare. In addition, when informed that lay citizens have concerns with changing animals instead of changing the system and worry that cattle resistant to heat would prevent farmers from planting trees, they said that one thing does not prevent the other: "having a more heat resistant animal doesn't mean you can fail to improve your management" (dairy farmer). They also offered arguments of how heat resistance would improve dairy cattle welfare: "it is also hot under the trees or inside the barn" (dairy farmer); "some animals have no access to shade due to social hierarchy of the herd" (dairy farmer) or "we live in an age of global warming" (extension agent).

- Most lay citizens (58\%) in the study are concerned about unexpected effects of the technology and said that there is not enough guarantee of safety. In addition, $50 \%$ consider GE ethically questionable and do not agree with genetically modifying animals.

- Genetically modifying animals is a concern for only $13 \%$ of farmers and professionals in the study. When asked about it in interviews dairy farmers and extension agents, despite being aware of the complexity involved in the genetic modification of organisms, show trust in science and affirm not having problems with the genetic modification of farm animals: "if there is no health problem for the animal nor the consumer, there is not a problem at all" (dairy farmer). This positive attitude is probably related to the history of livestock farming, given that dairy cattle breeds are constantly genetically enhanced through artificial selection to improve dairy production. 


\section{KEY MESSAGES:}

\section{BRAZILIAN FARMERS AND PROFESSIONALS INVOLVED WITH LIVESTOCK}

Brazilian farmers and professionals involved with livestock production share many values and views related to the use of GE to improve farm animal production.

They share positive attitudes in relation to new technologies and to genetic modification of organisms, therefore they perceive gene editing as a potential help to tackle problems in cattle production.

The economic benefit and the possibility to improve the quality of life of the producer, either by improving productivity, reducing expenses, or facilitating the management of animals is a decisive factor for the potential use of gene edited animals by this group.

Another decisive factor is the potential to improve farm animal welfare.

The high cost expected for implementing GE technology would be a barrier to its prompt adoption.

\section{BRAZILIAN LAY CITIZENS}

Lay citizens differ from stakeholders involved with livestock production, having more negative attitudes to genetic modification of organisms and worrying much more about the effects of this modification on the animals, humans, and the environment.

However, the potential to improve farm animal welfare as a reason for accepting farm animal GE is a shared value among all stakeholders. 


\section{WHAT ARE STUDY PARTICIPANTS' OPINIONS OF LABELING AND REGULATING PRODUCTS OF GENE EDITING?}

- Most stakeholders (67\%) in the study support the commercialization of products resulting from GE animals. For $53 \%$ of them the products should be labelled as genetically modified, for $10 \%$ the products should be labelled as transgenics, and for $4 \%$ there is no need for labelling.

- Only $18 \%$ of the participants opposed the approval of GE for commercialization ( $2 \%$ farmers, $5 \%$ professionals and $11 \%$ of the lay citizens). It is interesting to notice that more than half of those who consider GE unacceptable still do not oppose its approval for commercialization.

- According to dairy farmers and extension agents, labelling is a way to inform and maintain transparency with the public. They assume that a more informed public would become more accepting of technologies or systems considered necessary for them: "There will always be those who are against and those who are in favor. That depends on the clarification. If it is demonstrated by studies that GE has no problems, it is necessary to prepare society to absorb it" (extension agent).

Even if GM food products have gained approval for human consumption in many parts of the world, the labelling required in many countries is a recognition that the public wants to be informed about GMO in the food and to be able to choose to buy or eat it or not. Moreover, not labelling could result in loss of public trust in the industry, causing them to pursue non-genetically modified alternative products or choose to avoid all animal products.

\section{KEY MESSAGE}

The need of labelling for GE products is a shared value among all stakeholders and considered a way to inform and maintain transparency with consumers. 


\section{STUDY PARTICIPANTS' ATTITUDES IN RELATION TO FARM ANIMAL WELFARE}

Many surveys have found that stakeholders involved with farm animal production and lay citizens have contrasting views about animal welfare in livestock production systems and often contradictory political and ethical postures, which may have implications for animal welfare governance. As animal welfare is a key aspect for the acceptability of gene editing of farm animals, it is crucial to explore the understanding and importance given to this subject by all these groups.

\section{WHAT DEFINITION OF ANIMAL WELFARE BEST} FITS STAKEHOLDERS' UNDERSTANDING?

- The majority of the stakeholders (62\%) who participated in this survey define ${ }^{7}$ their understanding of animal welfare as: "concerns the way farmed animals are treated, providing them with a better quality of life." Although scientific studies have shown that Brazil's lay citizens have little awareness of livestock practices, the same studies have shown that citizens care and are critical of practices and systems they perceive as negative to the animals' quality of life, recognizing farm animals as deserving respect and dignity beyond the provision of basic needs.

- Despite differences in the views of what it is considered good welfare for farm animals among stakeholders, those involved with livestock production are also concerned with improving animal welfare in their farms, consider it as an important issue and a condition to accept GE applications: "If the animal is well, I am well" (dairy farmer).

\section{MANAGEMENT PRACTICES USED IN DAIRY FARMING}

- Lay citizens in this study are more favorable to dairy practices perceived as more "animal friendly" and "natural", such as rearing the calves with their mothers and in pasture-based systems, and less favorable to housing calves in individual pens or in compost barn housing systems.

- Farmers and professionals are favorable to most practices, especially to "new technologies", such as sexed semen and compost barn housing systems.

7 Options of animal welfare definition offered to participants were taken from the Special Eurobarometer 442: Attitudes of European towards Animal Welfare, 2015 ("It refers to the duty to respect all animals"; "It concerns the way farmed animals are treated, providing them with a better quality of life"; "It goes beyond animal protection"; "It is the same as animal protection" and "It contributes to better quality animal products"). 
- All groups surveyed are unfavorable to culling the newborn male calves in dairy farms (see Figure 7).

Figure 7 - Average acceptability of different dairy production practices by farmers (gray), professionals (yellow), and lay citizens (green) (weighted average from $1=$ not favorable to $5=$ totally favorable).

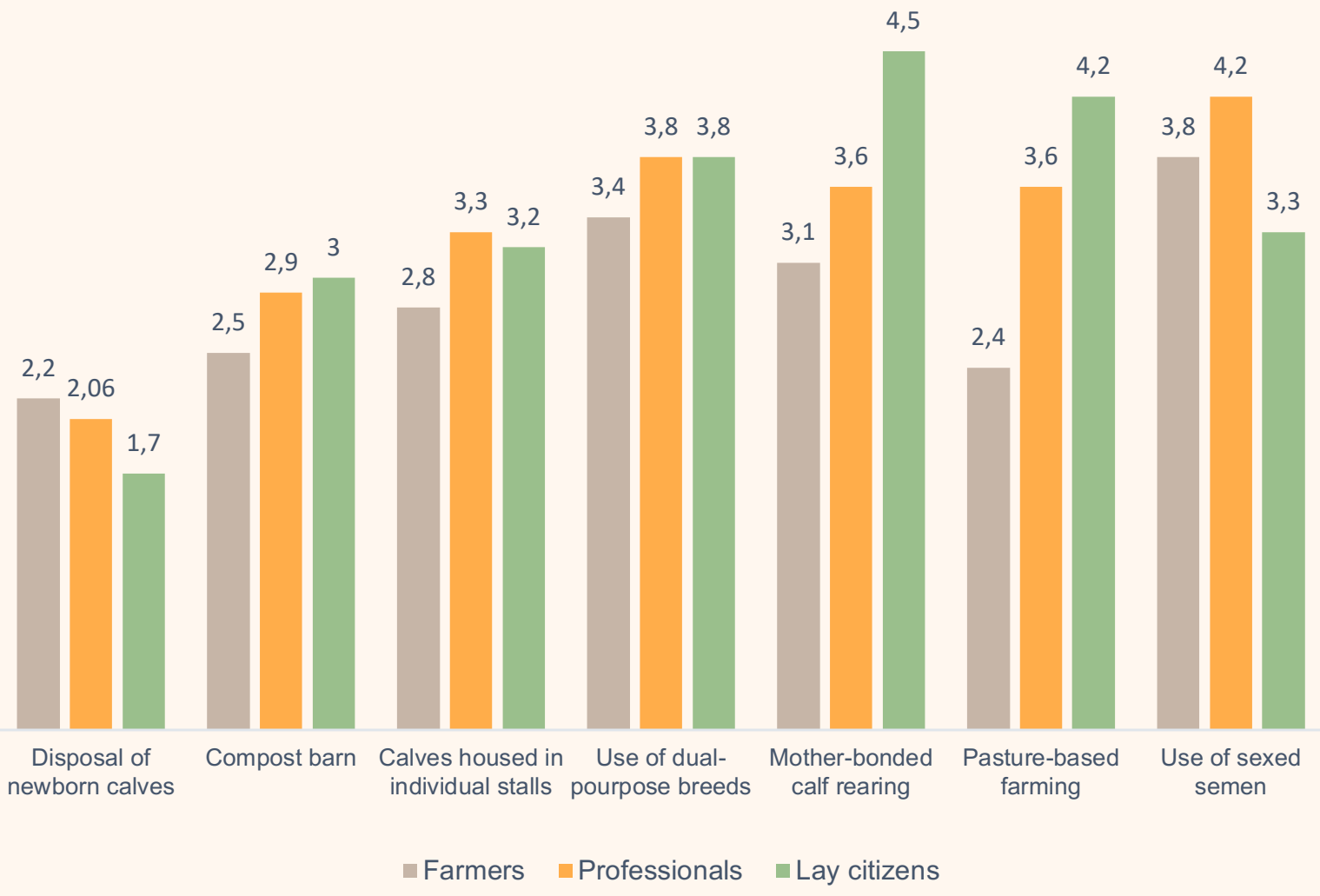

- Up to $50 \%$ of the farmers and professionals believe that lay citizens are not aware of current practices used by the animal industry (housing in individual stalls, practices that cause pain, early cow-calf separation and non-humane slaughter). Nearly $40 \%$ believe that lay citizens care about practices that cause pain and with the non-humane slaughter.

- Dairy farmers consider citizens to be ignorant of animal production systems and practices and argue that citizens' negative opinions are usually based on their limited knowledge on negative news publicized in the media. They consider that it is very important to inform the public: "I'm of the opinion that the more information the better" (dairy farmer). 


\section{REGULATING FARM ANIMAL WELFARE}

- Stakeholders expect public authorities to oversee farm animal welfare regulation. Most say that farm animal welfare is a matter for all citizens, "to be regulated by public authorities" (41\%) or "dealt jointly by public authorities and the animal industries" (42\%). Interviewees support animal welfare regulation and believe that public authorities should oversee regulation, "it is needed and otherwise (without regulation through legislation) it will not work" (extension agent); "we need the law because we see unbelievable things out there" (dairy farmer), they said.

- In general, stakeholders agree that:

> It is important to establish animal welfare standards that are recognized around the world $(87 \%)$.

> It is necessary to regulate practices through laws, it is not enough to self-regulate by industry through Codes of Good Practice (81\%).

> It is necessary to prohibit, through laws, practices that cause pain, such as castration or dehorning without anesthesia (72\%).

> It is necessary to regulate, through laws, the use of antibiotics in animal production $(72 \%)$.

> It is necessary to prohibit, through laws, the housing of animals in spaces that restrict their movement (64\%).

\section{KEYMESSAGE}

The need of legislation that guarantees farm animal welfare within production systems is a relevant shared value among all Brazilian stakeholders. 


\section{STUDY PARTICIPANTS' WAY OF FINDING INFORMATION AND WHO TO TRUST}

Many people lack interest, understanding and knowledge on science and technology. When there are decisions to take regarding the introduction of technological novelties in the market personal decisions may be highly influenced by trust in social institutions (scientists, industry, governmental institutions, etc.).

\section{WHICH ARE STUDY PARTICIPANTS' MAIN}

\section{SOURCES OF INFORMATION?}

- The most sought-after source of information is the Internet (77\%), followed by scientific articles (56\%). Television programs, specialized technical magazines and social media are consulted by near $30 \%$ of the study participants. Friends, WhatsApp and radio programs are used as a source of information by less than $10 \%$ of them.

\section{WHAT IS THE STUDY PARTICIPANTS' MOST TRUSTED SOURCE} TO INFORM THEM ON FARM ANIMAL PRODUCTION?

- For study participants, the most trusted source of information is that coming from science $(67 \%)$, and from specialized sites and media (21\%). Less than $5 \%$ trust more in governmental institutions, in animal industry information, or NGOs.

- Moreover, interviewees reported less trust in scientists working with industry or with the beneficiaries of the technology than in a scientist from universities or research centers. The reason for their lack of trust in the industry or NGOs is the belief that they only report on what interests them.

\section{KEY MESSAGE}

People seek reliable information and recognize who should be trusted. One way to gain the trust of stakeholders is to work together with those responsible for providing the information, in this case scientists and researchers from universities or research institutions. 


\section{TAKE HOME MESSAGES}

Stakeholders involved with livestock production in Brazil seem open to gene editing of dairy cows and believe that this tool can bring benefits to farmers, the animals, the environment, and consumers. Lay stakeholders, in contrast, see some risk and negative impacts, which they expect to be resolved before the technology appears in the supermarket. Society's perceptions of animal production play a crucial role in the future of the livestock industry. The treatment given to farm animals is an issue that increasingly calls for attention as people are becoming more interested in the ways by which animal-derived food is produced. The quality of food is also measured by the ethics of its production, including the consequences impinged upon the animals, the environment, producers, and consumers. Introducing practices and technologies that do not meet public expectations may erode the sustainability of the livestock systems (von Keyserlingk and Hötzel, 2015).

To achieve greater accordance between animal industry practices and society acceptance, collaboration of all stakeholders in the food chain and well-informed citizens will be extremely important to meet compromises and mutual benefits. In general, Brazilians have low objective knowledge on genetics and genetic modification. Provision of information may contribute to engage and form a public better able to discuss their views on issues related to the theoretical and applied aspects of gene editing technologies.

When the public is clearly informed trust is built, and trust is an important factor behind public acceptance (Siegrist, 2008). Dairy farmers and extension agents believe that product labelling is a way to inform and maintain transparency with the public. Discussions of the labeling of gene edited products should not wait for the launching of the products.

Regardless of their type of involvement with animal production, people want to maximize animal, human, and environmental outcomes; however, what each group considers best varies. It is crucial to include the lay voices in the debate and that it is done in a way that ensures representativeness, i.e., in sufficient numbers to represent different societal interests; the inclusion of few lay representatives in conversations full of experts does not guarantee that their voices will be heard (Bolton and von Keyserlingk, 202; Schuppli and Fraser, 2005).

The source and vehicles for such communication need to be carefully chosen. Trust in information sources about new technologies hinges, among other things, on credibility and shared values with providers of information (Costa-Font et al., 2008). Brazilians trust scientists from public institutions and are more suspicious of information coming from industry and other lobby groups. Gene editing has a growing presence in the Brazilian media, where it is often portrayed as a novel technology able to solve important problems. However, issues such as risks of the technology and doubts about how it may work once in large-scale use, or how science can help answer these and other questions are not clearly presented to the public in these vehicles. Brazilians are leading users of social media (STATISTA, 2021), a potential forum of exchange of information with the public on issues related to gene editing technologies. 
Lay citizens acknowledge positive impacts of gene editing of farm animals when the technology is associated with improvement of animal welfare, an issue that is attracting growing interest among Brazilians. Some practices that need attention of the dairy industry aiming to attend consumers' expectations are cow-calf separation, painful procedures, individual housing, and lack of pasture. Legislation to regulate farm animal welfare is welcome by all stakeholders, rather than self-regulation by voluntary codes of practice.

\section{IMPORTANT POINTS WHEN BUILDING STAKEHOLDERS DIALOGUE}

A challenge facing the use of GE in animal production is finding improved ways of dialogue between the different stakeholders. Dairy representatives and proposers of the gene editing technologies seeking social support, in knowledge of the relatively low acceptability by lay public presented here, should take the lead and start a dialogue:

- To maintain the dairy industry's social license to operate, the voices of the lay public must be considered.

- The dialogue must be organised in a way that allows all voices to be heard. The lay voices must be well represented to permit an active participation in the debate (e.g., be in a sufficient number, be well informed and motivated).

- It must not be restricted to information dissemination. Forums and round tables with the presence of different stakeholders are examples of events that make it possible.

- There is a need to prioritize communication on risks perceived by the public.

- Information must be open and easy to understand. There are well-known science communicators in Brazil that can help reach and inform lay persons through social media.

- The development of policies, product labelling, and practical recommendations regarding the use of gene editing in farm animals must be supported by the results of these dialogues. 


\section{REFERENCES}

Bolton, S.E.; von Keyserlingk, M.A.G. The Dispensable Surplus Dairy Calf: Is This Issue a "Wicked Problem" and where do we go from here? Front. Vet. Sci. 8:660934. 2021.

Bruce, A. Gene editing animals-part of a utopian future? In Food futures: ethics, science and culture, Olsson, A.S., Araújo, S.M., Vieira, M.F., Eds. Wageningen Academic Publishers: The Netherlands, 2016.

Eurobarometer. Europeans and Biotechnology in 2002. Directorate General Press and Communication, Public Opinion Analysis Unit. 19 p. 2002.

Lamas-Toranzo, I.; Guerrero-Sánchez, J.; Miralles-Bover, H.; Alegre-Cid, G.; Pericuesta, E.; Bermejo-Álvarez, P. CRISPR is knocking on barn door. Reproduction in Domestic Animals, 2017.

Menchaca, A. Sustainable Food Production: The Contribution of Genome Editing in Livestock. Sustainability, 13, 6788. 2021.

Proudfoot, C.; Mcfarlane, G.; Whitelaw, C.B.A.; Lillico, S.G. Livestock breeding for the 21st century: the promise of the editing revolution. Frontiers in Agricultural Science and Engeneering, 2020.

Schuppli CA, Fraser D. Factors influencing the effectiveness of research ethics committees. Source J Med Ethics. 33:294-301. 2007.

Siegrist, M. Factors influencing public acceptance of innovative food technologies and products. Trends in Food Science \& Technology 19, 603-608. 2008.

Shriver, A. Prioritizing the protection of welfare in gene-edited livestock. Anim. Front., 2020.

Sonstegard, T.S.; Carlson, D.F.; Fahrenkrug, S.C. Genetically modified animals having increased heat tolerance. 2017.

STATISTA. Leading countries based on Instagram audience size as of January 2021. In: https://www.statista.com/statistics/578364/countries-with-most-instagram-users/. Accessed on: September 21.

Tan, W.; Carlson, D.F.; Lancto, C.A.; Garbe, J.R.; Webster, D.A.; Hackett, P.B.; Fahrenkrug, S.C. Efficient nonmeiotic allele introgression in livestock using custom endonucleases. Proc. Natl Acad. Sci. USA, 2013.

von Keyserlingk, M.A.G.; Hötzel, M.J. The ticking clock: Addressing farm animal welfare in emerging countries. J. Agric. Environ. Ethics, 28, 179-195, 2015. 
